\title{
Over-expression of snakin-2 and extensin-like protein genes restricts pathogen invasiveness and enhances tolerance to Clavibacter michiganensis subsp. michiganensis in transgenic tomato (Solanum lycopersicum)
}

\author{
Vasudevan Balaji • Christine D. Smart
}

Received: 10 December 2010/Accepted: 18 March 2011/Published online: 9 April 2011

(C) Springer Science+Business Media B.V. 2011

\begin{abstract}
Two tomato proteins were evaluated by over-expression in transgenic tomato for their ability to confer resistance to Clavibacter michiganensis subsp. michiganensis (Cmm). Snakin-2 (SN2) is a cysteinerich peptide with broad-spectrum antimicrobial activity in vitro while extensin-like protein (ELP) is a major cell-wall hydroxyproline-rich glycoprotein linked with plant response to pathogen attack and wounding. Tomato plants, cultivar Mountain Fresh, were transformed via Agrobacterium tumefaciens harboring a binary vector for expression of the full-length SN2 gene or ELP cDNA under the regulation of the CaMV $35 \mathrm{~S}$ promoter. Molecular characterization of PCRpositive putative $T_{0}$ transgenic plants by Northern
\end{abstract}

The nucleotide sequence of the tomato snakin-2 gene reported in this paper is deposited in GenBank under the accession number HQ008860.

Electronic supplementary material The online version of this article (doi:10.1007/s11248-011-9506-x) contains supplementary material, which is available to authorized users.

V. Balaji · C. D. Smart $(\bowtie)$

Department of Plant Pathology and Plant-Microbe Biology, New York State Agricultural Experiment Station, Cornell University, Geneva, NY 14456, USA e-mail: cds14@cornell.edu

Present Address:

V. Balaji

Plant Biology Division, Samuel Roberts Noble

Foundation, Ardmore, OK 73401, USA analysis revealed constitutive over-expression of $S N 2$ and ELP mRNA. Junction fragment analysis by Southern blot showed that three of the four SN2 overexpressing $\mathrm{T}_{0}$ lines had single copies of complete T-DNAs while the other line had two complete T-DNA copies. All four ELP over-expressing $\mathrm{T}_{0}$ lines had a single copy T-DNA insertion. Semi-quantitative RTPCR analysis of $\mathrm{T}_{1}$ plants revealed constitutive overexpression of SN2 and ELP. Transgenic lines that accumulated high levels of $S N 2$ or ELP mRNA showed enhanced tolerance to $\mathrm{Cmm}$ resulting in a significant delay in the development of wilt symptoms and a reduction in the size of canker lesions compared to nontransformed control plants. Furthermore, in transgenic lines over-expressing SN2 or ELP bacterial populations were significantly lower (100-10,000-fold) than in non-transformed control plants. These results demonstrate that SN2 and ELP over-expression limits Cmm invasiveness suggesting potential in vivo antibacterial activity and possible biotechnological application for these two defense proteins.

Keywords Tomato Clavibacter michiganensis subsp. michiganensis - Snakin-2 - Extensin-like protein · T-DNA

\section{Introduction}

Tomato is one of the most economically important vegetable crops worldwide, but the majority of the 
commercial cultivars are susceptible to a wide range of plant pathogens. Among the bacterial pathogens of tomato, Clavibacter michiganensis subsp. michiganensis $(\mathrm{Cmm})$, which causes bacterial canker and wilt disease (Davis et al. 1984), is considered the most important accounting for severe economic losses that may become devastating to tomato production worldwide (Jones et al. 1991). Unlike most plant bacterial pathogens, which are Gram-negative, $\mathrm{Cmm}$ is a Gram-positive quarantine organism in the context of international agriculture. $\mathrm{Cmm}$ is transmitted by contaminated seeds, transplants, infected tomato residues in the soil, and can be spread in water and wind-driven rain. $\mathrm{Cmm}$ bacteria enter the plant through wounds or natural openings, find their way into the xylem, and develop a systemic infection (Jahr et al. 1999). Colonization of xylem vessels leads to the appearance of typical disease symptoms that include unilateral wilting of leaves, leaflet marginal necrosis, bird's-eye lesions on fruit and development of canker lesions on the stem. Neither resistant commercial tomato cultivars nor effective chemical control are available to manage $\mathrm{Cmm}$. Consequently, a transgenic approach using tomato genes that can curtail and prevent pathogen proliferation and spread constitutes an interesting and potentially effective approach to reduce losses.

In recent years important insight into the molecular mechanisms of $\mathrm{Cmm}$ pathogenicity has been achieved (Gartemann et al. 2003), and the genome sequence of a $\mathrm{Cmm}$ strain has been completed (Gartemann et al. 2008). Studies on virulence determinants have shown that $\mathrm{Cmm}$ carries two plasmids (pCM1 and pCM2) encoding genes involved in pathogenicity (Meletzus et al. 1993). A recent study demonstrated the interdependence of chromosomal and plasmid-located virulence gene expression in $\mathrm{Cmm}$ for a successful infection in tomato (Chalupowicz et al. 2010).

To counter pathogen invasion, plants have evolved a variety of potent defense mechanisms, including the synthesis of low-molecular weight peptides with antimicrobial activity (Selitrennikoff 2001) and cell wall fortification. More than 500 antimicrobial peptides (AMPs) have been discovered in plants and animals, in which they play important roles as key components of the innate defense against invading microorganisms (Lopez-Solanilla et al. 2003). Snakin-1 (SN1) and snakin-2 (SN2) are two AMPs isolated from Solanum tuberosum cv. Desireé that have been found to be active against important pathogens in vitro (Berrocal-Lobo et al. 2002; Segura et al. 1999). SN1 and SN2 amino acid sequence alignments show similarity with the GAST1 (giberellic acid stimulated transcript) gene from tomato (Shi et al. 1992) and GASA family from Arabidopsis (giberellic acid stimulated in Arabidopsis), and they have been classified as members of a novel snakin/ GASA family (Berrocal-Lobo et al. 2002). In tomato, only one GAST member has been identified and characterized (Shi et al. 1992). However, the possibility for existence of other members cannot be eliminated. Support for this notion is strengthened by the fact that homologous gene members of GAST/ GASA family have been identified and characterized in a wide range of monocot and dicot species (Ben-Nissan and Weiss 1996; Furukawa et al. 2006; Kotilainen et al. 1999). All of these genes encode small polypeptides that share the common structural features of an $\mathrm{N}$-terminal putative signal sequence, a highly divergent intermediate region and a conserved 60 amino-acid carboxyl-terminal domain containing 12 conserved cysteine residues.

A previous study in potato on expression kinetics showed that StSN2 mRNA was detected in all tissues analyzed except for roots, stolons and sepals. The steady state level of StSN2 mRNA was highest in tubers, stamens, petals and carpels (Berrocal-Lobo et al. 2002). The StSN2 showed differential expression patterns in response to biotic and abiotic stresses. Interestingly, gene expression was down-regulated after inoculation with bacterial pathogens Ralstonia solanacearum and Erwinia chrysanthemi (Berrocal-Lobo et al. 2002). A similar observation was documented from our previous study where the tomato SN2 gene was down-regulated less than twofold upon $\mathrm{Cmm}$ infection (Balaji et al. 2008). Down-regulation of defense genes by some pathogens has been suggested as a mechanism to overcome plant defense (Jakobek et al. 1993). SN1 and SN2 were reported to be active in vitro against Clavibacter michiganensis subsp. sepedonicus (Cms, closely related to $\mathrm{Cmm}$ ) and fungal species such as Fusarium solani, Fusarium culmorum, Bipolaris maydis and Botrytis cinerea (Berrocal-Lobo et al. 2002; Segura et al. 1999). Overexpression of the SN1 gene was shown to confer enhanced resistance in transgenic potato plants to Rhizoctonia solani and Erwinia caratovora (Almasia 
et al. 2008). Although it was reported that SN1 and SN2 cause rapid in vitro aggregation of both Grampositive and Gram-negative bacteria, a direct correlation between aggregation and antimicrobial activity was not established (Berrocal-Lobo et al. 2002; Segura et al. 1999). We recently found that silencing the tomato SN2 homolog in Nicotiana benthamiana increases susceptibility to $\mathrm{Cmm}$ and enhances wilt disease development (Balaji et al. 2011), thereby showing a role for $S N 2$ gene in defense response.

Strengthening of the cell wall and modification of its composition is a common plant defense response to pathogen invasion. Cell wall proteins are among the most variable contributors to plant cell wall composition in terms of overall protein content and type (Cassab 1998; Sommer-Knudsen et al. 1998). Hydroxyproline-rich glycoproteins (HRGPs), of which extensins are the most well studied, are one of the major classes of protein present in the cell wall. Previous research has indicated that extensins may play a role in plant response to pathogen attack and wounding (reviewed by Bowles 1990). Extensins may also provide anchorage for lignification, further strengthening the cell wall (Showalter and Rumeau 1990; Showalter and Varner 1989). Research on a number of host-pathogen systems has shown that extensin levels increase in response to pathogen ingress and proliferation (Davies et al. 1997; Hauck et al. 2003). One study convincingly demonstrated a functional linkage between extensin synthesis and plant resistance to pathogen attack (Wei and Shirsat 2006), as EXT1 over-expressing transgenic Arabidopsis were resistant to Pseudomonas syringae pv. tomato DC3000. Transcriptome analysis of the tomato- $\mathrm{Cmm}$ compatible interaction revealed that tomato extensin-like protein $(E L P)$ encoding cDNA was up-regulated 12-20-fold at 4 and 8 days postinoculation (dpi) after $\mathrm{Cmm}$ infection (Balaji et al. 2008). Furthermore, silencing a $N$. benthamiana homolog of the tomato ELP enhanced susceptibility to $C m m$ infection and induced early wilting in silenced $N$. benthamiana plants when compared to the non-silenced control (Balaji et al. 2011).

Despite the evidence linking AMPs and ELP to plant defense, there has been a lack of data showing that accumulation of $S N 2$ or ELP gene products actually slows or stops the progress of $\mathrm{Cmm}$ invasion. In the present study, we used a gain-of-function approach to study gene function in vivo by constitutively over-expressing SN2 and ELP in transgenic tomato plants and assessing their resistance against Cmm.

\section{Materials and methods}

Biological materials and growth conditions

Seeds of tomato, Solanum lycopersicum cv. Mountain Fresh were surface-sterilized for $2 \mathrm{~min}$ in $70 \%$ alcohol and washed three times with sterilized water. Seeds were then treated with hypochlorite solution containing $4 \%$ active chlorine for $20 \mathrm{~min}$ under shaking conditions and rinsed five times with sterile water. Surface-sterilized seeds were spread on a sterile Whatman filter paper $(7 \mathrm{~cm}$ circle) to remove excess water from the surface and 10 seeds were placed in a Magenta box containing $50 \mathrm{ml}$ of halfstrength Murashige and Skoog (1962) (MS) medium [4.33 g/l MS salts (Phytotechnology Laboratories, Shawnee Mission, KS), $100 \mathrm{mg} / \mathrm{l}$ myoinositol (Sigma, St. Louis, MO) $0.5 \mathrm{mg} / \mathrm{l}$ thiamine- $\mathrm{HCl}$ (Sigma), $0.5 \mathrm{mg} / \mathrm{l}$ pyridoxine-HCl (Sigma), $0.5 \mathrm{mg} / \mathrm{l}$ nicotinic acid (Sigma), $20 \mathrm{~g} / \mathrm{l}$ sucrose (Fischer Scientific), $8 \mathrm{~g} / \mathrm{l}$ Agar-Agar (Sigma), $\mathrm{pH}$ 5.8] and germinated at $24 \pm 1^{\circ} \mathrm{C}$ during a $16 \mathrm{~h}$ light and $8 \mathrm{~h}$ dark photoperiod. Eight-day-old seedlings were used to excise cotyledon explants for transformation. The bacterial strains LBA4404 of Agrobacterium tumefaciens and 04101 of $\mathrm{Cmm}$ were used throughout this study. Cmm 04101 was isolated from an infected tomato field in New York, USA. Bacterial strains were stored as glycerol stocks at $-80^{\circ} \mathrm{C}$.

\section{Binary vector construction}

Genomic DNA from tomato leaf samples was extracted as described by Rogers and Bendich (1988). The snakin-2 (SN2) complete open reading frame (776 bp) was amplified from tomato genomic DNA template by a PCR assay using specific primers (Table S1), cloned in the commercial vector pGEM-T (Promega, Madison, WI, USA), and sequence was determined in both directions using the centralized sequencing facility (Cornell University, Ithaca, NY, USA). Like wise, the full-length extensin-like protein 
(ELP) encoding cDNA sequence (414 bp) was amplified by PCR using gene-specific primers (Table S1) from cDNA template reverse transcribed from tomato leaf-derived total RNA isolated using a RNeasy Plant Mini Kit (Qiagen Inc, Valencia, CA). The amplified ELP cDNA was then cloned into pGEM-T and sequenced. Cloned SN2 and ELP sequences were analyzed by the BioEdit Sequence Alignment Editor and multiple sequence analysis was performed using CLUSTALW version 1.8 (Thompson et al. 1994). For construction of binary vectors, the full-length 776 bp SN2 gene sequence was amplified by PCR using initial pGEM-T clone (containing the SN2 insert) as template and primer pair 5'-CGCGGATCCTTAAGGGCATTTACGTTT GTTGCC-3' (forward) and 5'-CATGCCATGGAT GGCCATTTCGAAAGCTCTC-3' (reverse), restriction digested with $\mathrm{BamHI} / \mathrm{NcoI}$ (in bold) and cloned into corresponding sites of the expression vector pEPT8 (Ling et al. 1997) between the Cauliflower mosaic virus (CaMV) 35S promoter and terminator sequences. This cassette was then sub-cloned into the HindIII site of the binary vector pGA482G (Chee et al. 1989) harboring a kanamycin resistance cassette, giving rise to the final construct pGA482G$S N 2$. The full-length $E L P$ cDNA was excised from the primary pGEM-T clone as an NcoI/SalI fragment and inserted into pEPT8 cut with the same enzymes. The entire cassette was then cloned into the HindIII site of pGA482G resulting in the recombinant binary plasmid pGA482G-ELP. The binary constructs were confirmed by a detailed restriction analysis and introduced into A. tumefaciens vir helper strain LBA4404 (Hoekema et al. 1983) by electroporation. Standard molecular procedures were carried out as described by Sambrook et al. (1989).

\section{Tomato transformation}

Transformation and regeneration was performed as described previously (Van Eck et al. 2006) with a minor modification in the growth medium used for culturing A. tumefaciens. Bacterial strain LBA4404 harboring the binary plasmid pGA482G-SN2 or pGA482G-ELP was grown in liquid $\mathrm{AB}$ minimal medium (Chilton et al. 1974) containing genta mycin $50 \mathrm{mg} / \mathrm{l}$, instead of YM (yeast-mannitol) medium.
DNA extraction, PCR and southern analysis

Genomic DNA from non-transformed (NT) control and putative kanamycin-resistant plants was isolated using a CTAB method (Rogers and Bendich 1988) and was analyzed by PCR using a primer pair specific for the nptII coding sequence (Table S1). For Southern blot analysis, $12 \mu \mathrm{g}$ of genomic DNA was digested with XhoI or HindIII (for SN2-transformed plants) and BamHI or HindIII (for ELP-transformed plants) and subjected to agarose $(0.8 \%)$ gel electrophoresis. DNA was transferred to Hybond $\mathrm{N}^{+}$Nylon Membrane (GE health care, PA), and the membrane was exposed to UV cross-linking (Spectrolinker ${ }^{\mathrm{TM}}$ XL-1000, Spectronics Corporation, NY). Digoxygenin (DIG)-labeled probes (776 bp full-length SN2 gene and $414 \mathrm{bp}$ full-length ELP cDNA) were prepared by PCR according to the manufacturer's labeling kit system (Roche Diagnostics, USA) employing DIG-conjugated dUTPs, primers specific for $S N 2$ or ELP (Table S1) and the pGEM-T plasmid clone containing the full-length SN2 gene or ELP cDNA sequence as template. Hybridization was carried out for $16 \mathrm{~h}$ at $40^{\circ} \mathrm{C}$ using buffers supplied in the kit. Membranes were washed once in $2 \times \mathrm{SSC} /$ $0.1 \%$ SDS for $5 \mathrm{~min}$ at room temperature followed by three washes in $0.5 \times \mathrm{SSC} / 0.1 \%$ SDS with each wash for $10 \mathrm{~min}$ at $65^{\circ} \mathrm{C}$. Blocking, washing and signal detection steps were carried out according to the manufacturer's Detection System (Roche Diagnostics, USA). Membranes were exposed for $2 \mathrm{~h}$ to X-ray film (Kodak, USA) for autoradiography.

RNA extraction, Semi-quantitative RT-PCR and northern blot analysis

Leaf and stem tissues were immediately frozen in liquid nitrogen after harvest and stored at $-80^{\circ} \mathrm{C}$. RNA extraction was carried out following the procedure described by Chang et al. (1993) and treated with RNase free DNase. RNA samples $(2.5 \mu \mathrm{g})$ were reverse transcribed in a $20 \mu \mathrm{l}$ reaction volume as previously described (Balaji et al. 2008). One $\mu$ of the RT reaction mixture was used for PCR in a $50 \mu \mathrm{l}$ reaction volume containing 1 unit of Taq DNA polymerase (New England Biolabs, Ipswich, MA), $200 \mu \mathrm{M}$ of each dNTP, and $300 \mathrm{nM}$ of forward and reverse primers specific for $S N 2$ and ELP (Table S1). Each PCR reaction included an 
initial denaturation at $94^{\circ} \mathrm{C}$ for $2 \mathrm{~min}$, followed by 45 cycles at $94^{\circ} \mathrm{C}$ for $30 \mathrm{~s}$, annealing for $30 \mathrm{~s}\left(48^{\circ} \mathrm{C}\right.$ for $E L P, 55^{\circ} \mathrm{C}$ for $S N 2$ and $S l E F-a$ ) and an extension at $72^{\circ} \mathrm{C}$ for $1 \mathrm{~min}$. A $10 \mu \mathrm{l}$ aliquot of each PCR reaction mixture was removed after 20,30 and 40 cycles, separated on a $1 \%$ agarose gel and visualized by staining with ethidium bromide. To ensure that equal amounts of cDNA were used for NT control and transgenic plants, parallel reactions were run with tomato transcription elongation factor SlEF$a$ (X53043) specific-primers (Table S1) as a control.

For RNA gel blot analysis, $15 \mu \mathrm{g}$ of total RNA was electrophoretically resolved in a $1.0 \%$ formaldehydeagarose gel using MOPS buffer (Sigma) and transferred to Hybond $\mathrm{N}^{+}$Nylon Membrane for $16 \mathrm{~h}$ followed by UV cross-linking. Probes (315 bp fulllength SN2 cDNA and 414 bp full-length ELP cDNA) were synthesized by PCR labeling with DIG-dUTPs as described in the DIG Labeling Kit (Roche Diagnostics, USA). Hybridizations were performed for $16 \mathrm{~h}$ at $50^{\circ} \mathrm{C}$ in a commercial DIG-easy hybridization solution (Roche Diagnostics, USA). Membrane was washed once in $2 \times \mathrm{SSC} / 0.1 \% \mathrm{SDS}$ for $5 \mathrm{~min}$ at room temperature and thrice in $0.1 \times \mathrm{SSC} / 0.1 \% \mathrm{SDS}$ for $10 \mathrm{~min}$ at $68^{\circ} \mathrm{C}$. Blocking with anti-DIG-AP conjugate and signal detection was performed according to the manufacturer instructions. Membranes were exposed for $1 \mathrm{~h}$ to X-ray film for autoradiography.

\section{Segregation analysis}

Seeds collected from three selfed $\mathrm{T}_{0}$ tomato plants over-expressing SN2 (S6, S9, S14) or ELP (E12, E22, E24) were screened for kanamycin resistance. Surface-sterilized seeds were germinated on halfstrength MS medium containing $100 \mathrm{mg} / \mathrm{l}$ kanamycin at $24 \pm 1^{\circ} \mathrm{C}$ during a $16 \mathrm{~h}$ light and $8 \mathrm{~h}$ dark photoperiod. As a control, 30 seeds from NT control plants were germinated on the same medium with and without kanamycin. After 10 days, kanamycin-resistant $\left(\operatorname{Kan}^{\mathrm{R}}\right)$ and kanamycin-sensitive $\left(\operatorname{Kan}^{\mathrm{S}}\right)$ seedlings were scored and the data was validated using a $\chi^{2}$ test. Seedlings resistant to kanamycin were transferred to soil and maintained in the greenhouse.

\section{Bacterial resistance bioassays}

For bacterial resistance bioassays, $\mathrm{Cmm}$ bacteria were grown overnight at $28^{\circ} \mathrm{C}$ with shaking, in
Luria-Bertani broth medium. Bacteria were pelleted by centrifugation at $5,400 \times g$ for $20 \mathrm{~min}$, washed twice, diluted to $1 \times 10^{8} \mathrm{cfu} / \mathrm{ml}$ in $10 \mathrm{mM} \mathrm{MgCl}_{2}$, and used to inoculate plants. Thirty, 4-week-old $\mathrm{T}_{1}$ plants of each transgenic line (three lines per gene), as well as NT control plants, were inoculated with $5 \mu \mathrm{l}$ of the bacterial suspension in the stem at the first leaf node up from the crown using a $1 \mathrm{ml}$ syringe fitted with a 30-gauge needle. Five plants of each transgenic line and the NT control were mockinoculated with $10 \mathrm{mM} \mathrm{MgCl}$ solution. Plants were kept in the greenhouse (at approximately $25^{\circ} \mathrm{C}$ with $16 \mathrm{~h}$ light per day) and treatments were arranged in a completely random design. The susceptibility of transgenic and NT control plants to $\mathrm{Cmm}$ was estimated by monitoring the appearance of wilt symptoms on a daily basis in the group of 30 plants over a period of 20 days. For a quantitative estimation of susceptibility to $\mathrm{Cmm}$, a wilting index, defined as the number of days required until $50 \%$ of the plants showed first wilt symptoms, was determined as described elsewhere (Meletzus et al. 1993; Balaji et al. 2008, 2011). In addition, in planta bacterial growth was measured at 4 and 8 days post-inoculation (dpi) by grinding four stem pieces $(1 \mathrm{~cm}$ in length) in $10 \mathrm{mM} \mathrm{MgCl}{ }_{2}$ and plating serially diluted samples on D2ANX medium plates containing nalidixic acid, polymixin sulfate and cycloheximide at 28, 10 and $100 \mathrm{mg} / \mathrm{l}$, respectively (Chun 1982). Each stem piece was derived from an independent plant and was cut at $1 \mathrm{~cm}$ above the $\mathrm{Cmm}$-inoculation site. After incubation of the plates at $28^{\circ} \mathrm{C}$ for $4-5$ days, the number of colony forming units per gram of tissue $(\mathrm{cfu} / \mathrm{g})$ was determined for each sample.

\section{Results}

Isolation and bioinformatics analysis of $S N 2$ and $E L P$ sequences

The nucleotide sequence of potato snakin-2 (SN2) cDNA (AJ312904) was used as query in the BLASTN search against the Solanaceae Genomics Network (SGN) tomato EST database. Blast search identified a tomato homolog that had 98 and $95 \%$ identity with potato $S N 2$ at the nucleotide and amino acid level, respectively. The full-length $S N 2$ gene was PCRamplified from tomato genomic DNA using SN2 
gene-specific primers (Table S1) and sequenced. Analysis of the nucleotide sequence revealed that the 776 bp full-length SN2 gene of tomato (HQ008860) encompassed 3 exons and 2 introns, similar to that of the potato $S N 2$ gene (AJ312424). Nucleotide sequence comparison of tomato and potato $S N 2$ gene sequences revealed $81 \%$ identity. All nucleotide mismatches were found in the introns, except for five bp changes in the exons resulting in $95 \%$ identity at the amino acid level. We were not successful in obtaining full-length SN2 cDNA after many attempts. Nucleotide sequencing of multiple cDNA clones reverse transcribed from total RNA extracted from non-transformed plants revealed truncation of $6-10 \mathrm{bp}$ at the $5^{\prime}$ end including the start codon ATG. Hence, we decided to use the fulllength genomic SN2 gene for tomato transformation.

To amplify the full-length ELP encoding sequence, tomato total RNA was reverse transcribed into cDNA and used as the template for PCR with ELP genespecific primers (Table S1). Nucleotide sequencing of the cloned RT-PCR product revealed $100 \%$ identity to the single copy tomato ELP cDNA sequence (AJ133 600) reported in the GenBank database.

Transgenic tomato plants

Transgenic tomato plants were generated to test whether constitutive over-expression of the SN2 and ELP genes leads to disease resistance/tolerance against $\mathrm{Cmm}$. Prior to transformation, a sensitivity assay was performed with a wide range of kanamycin concentrations $(0,25,50,75,100$ and $125 \mathrm{mg} / \mathrm{l})$ to determine the minimum effective dose required to inhibit callus and shoot bud formation in cotyledon explants. A kanamycin concentration of $75 \mathrm{mg} / \mathrm{l}$ was identified as the most appropriate dose to inhibit regeneration of sensitive explants, and this concentration was later used as the selection dose in tomato transformations (Fig. S1). Eight-day-old cotyledon explants were transformed with an A. tumefaciens strain LBA4404 harboring pGA482GSN2 (Fig. S2A) or pGA482GELP (Fig. S2B) and the putative kanamycin-resistant shoots were verified by PCR with $n p t$ II-specific primers (Table S1) to confirm transformation. A $625 \mathrm{bp}$ fragment corresponding to the $n p t I \mathrm{I}$ coding sequence was amplified in 10 out of 15 preselected plants transformed with the SN2 gene (Fig. $\mathrm{S} 3 \mathrm{~A}$ ) and in 23 of 27 plants transformed with the ELP full-length cDNA sequence (Fig. S3B). Transgenic lines were referred to as ' $\mathrm{S}$ ' and ' $\mathrm{E}$ ' for the $S N 2$ and $E L P$ gene, respectively with each number representing an independent transgenic plant.

Expression of SN2 and ELP genes in transgenic tomato lines

Ten SN2-transformed $\mathrm{T}_{0}$ plants (S2, S4-S6, S9 and S11-S15) and 20 ELP-transformed $\mathrm{T}_{0}$ plants (E1-E3, E5-E8, E10-E16, E18-E22 and E24) were analyzed for the expression of the SN2 and ELP genes, respectively. To analyze $S N 2$ and ELP mRNA accumulation, northern blot analysis was performed using total RNA extracted from leaf tissues of SN2and ELP-transformed plants and corresponding partial SN2 or full-length ELP cDNA probes. The $S N 2$ cDNA probe had a truncation of $6 \mathrm{bp}$ including the start codon ATG at the $5^{\prime}$ end. Transgenic plants S6, S9, S11, S12, S14 and S15 showed significantly higher levels of SN2 mRNA compared with nontransformed (NT) control plants (Fig. 1a). Analysis of ELP gene expression showed that transgenic plants E1, E3, E10, E11, E12, E13, E14, E15, E21, E22 and E24 accumulated higher levels of ELP mRNA compared with NT control plants (Fig. 1b).

Southern blot analysis of $\mathrm{T}_{0}$ plants for copy number determination

Total DNA extracted from the NT control and four primary transformants $\left(\mathrm{T}_{0}\right)$ over-expressing $S N 2$ ( $\mathrm{S} 6$, S9, S14 and S15) or ELP (E3, E12, E22 and E24)) was used for Southern blot analysis to confirm the transfer of SN2 and ELP transgene, respectively. Genomic DNA was digested with HindIII and probed with the $776 \mathrm{bp}$ full-length $S N 2$ gene or the $414 \mathrm{bp}$ full-length ELP cDNA sequence. The SN2 transgene was distinguished from the endogenous $S N 2$ gene fragments on the basis of hybridization of the SN2 probe to a $1.65 \mathrm{~kb}$ HindIII fragment (Fig. S2A). All four $\mathrm{T}_{0}$ plants showed the presence of the $1.65 \mathrm{~kb}$ internal T-DNA fragment (Fig. 2a, left), which was not detected in DNA of the NT control plants. The additional fragments of 3.9 and $4.9 \mathrm{~kb}$ detected in the control and primary transformants (Fig. 2a, left) may very well correspond to two copies of the endogenous tomato SN2 gene, as there is no internal HindIII site in the sequence. However, this would need to be verified by additional experiments. The differences in 
A

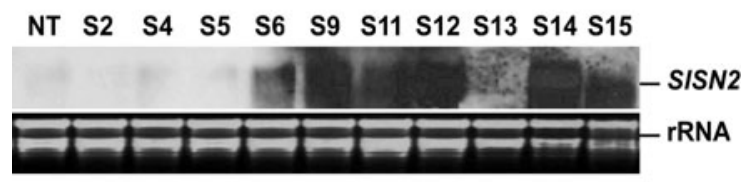

B

NT E1 E2 E3 E5 E6 E7 E8 E10 E11 E12

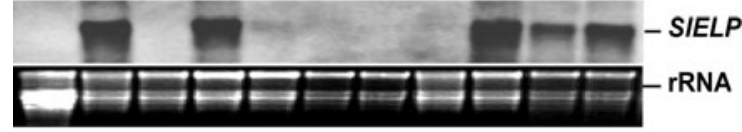

NT E13 E14 E15 E16 E18 E19 E20 E21 E22 E24

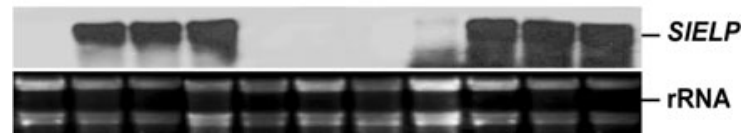

Fig. 1 Northern blot analysis to assess over-expression of the snakin-2 (SN2) and extensin-like protein (ELP) mRNA in transgenic $\mathrm{T}_{0}$ tomato plants. Ten plants transformed with the SN2 gene (a) and 20 plants transformed using a binary vector harboring the ELP cDNA (b) that were PCR positive with $n p t$ II-specific primers were analyzed by northern hybridization along with the non-transformed (NT) control plants. Total RNA $(15 \mu \mathrm{g})$ was extracted and hybridized with DIG-labeled partial $S N 2$ or full-length ELP cDNA probes. The ethidium bromide stained gels of corresponding northern blots are shown below each blot. $S$ and $E$ denote plants transformed with the $S N 2$ gene and ELP cDNA, respectively

the level of hybridization of the endogenous copies between the different tomato lines could be due to variations between samples despite loading of quantified DNA and differences in the amount of input DNA recovered during processing of samples after restriction digestion. Hybridization performed with the ELP cDNA as a probe revealed that DNA from all four primary transformants, but not from NT plants, hybridize to a $1.35 \mathrm{~kb}$ HindIII fragment that distinguished the ELP transgene from the endogenous single copy gene (2.4 kb band) (Fig. 2b, left).

Additional Southern blots were performed to determine the T-DNA copy number by junction fragment analysis. The 776 bp SN2 gene and 414 bp ELP cDNA sequences were used as probes to analyze left border (LB) junction fragments in four primary transformants $\left(\mathrm{T}_{0}\right)$ over-expressing $S N 2$ and $E L P$, respectively. XhoI digestion of plant DNA from SN2 transformants followed by hybridization with the SN2 probe would result in LB junction fragments longer than $4.6 \mathrm{~kb}$ (Fig. S2A). All four $\mathrm{T}_{0}$ plans generated junction fragments longer than $4.6 \mathrm{~kb}$ (Fig. 2a, right). Three
A
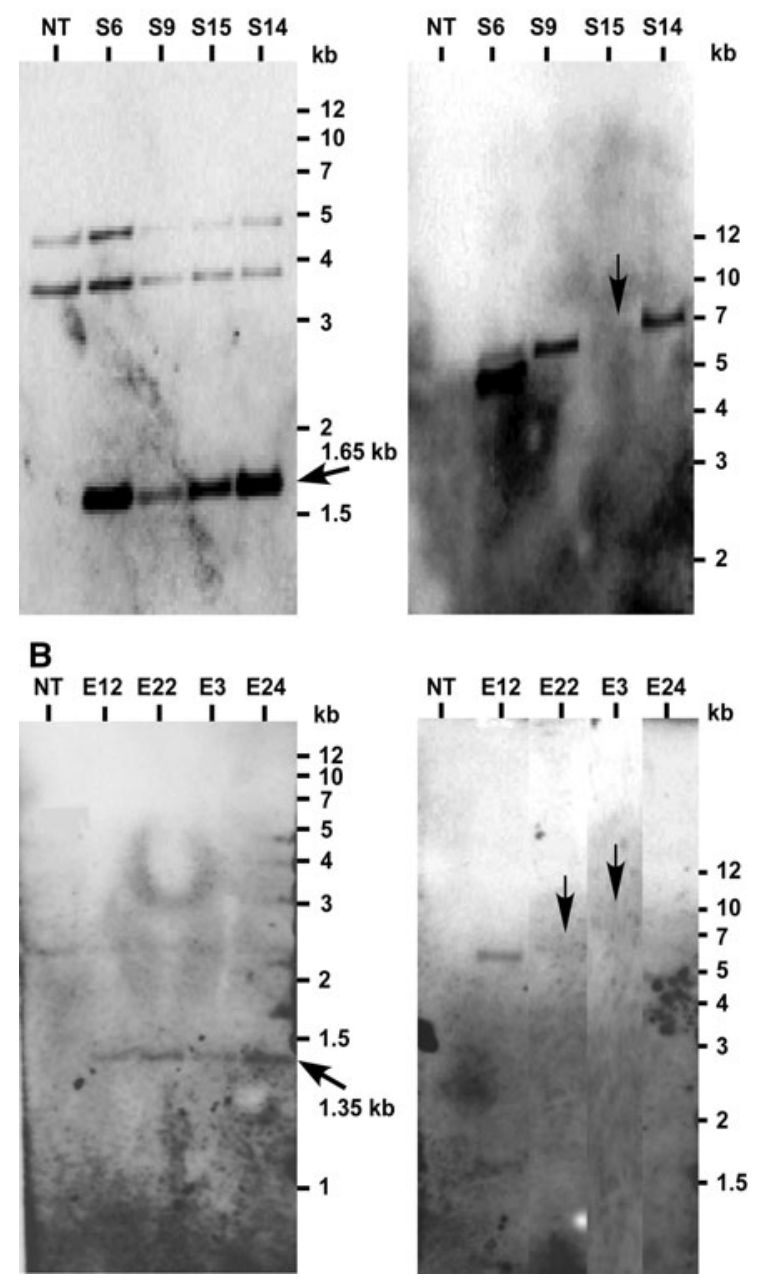

Fig. 2 Southern blot analysis of the $T_{0}$ transgenic tomato plants using snakin-2 (SN2) gene (a) and extensin-like protein $(E L P)$ cDNA (b) probes. Twelve microgram aliquots of DNA from four SN2-transformed plants (S6, S9, S14 and S15) and a non-transformed plant (NT) were digested using HindIII (a, left) or XhoI (a, right) and analyzed. Genomic DNA from four ELP cDNA-transformed plants (E3, E12, E22, E24) and a non-transformed plant (NT) were digested with HindIII (b, left) or $B a m H I ~(b, r i g h t)$ and analyzed. The digested genomic DNA was electrophoresed on a $0.8 \%$ agarose gel in $1 \times$ TAE buffer and transferred to a positively charged nylon membrane. The probes, SN2 gene (776 bp) and ELP cDNA (414 bp), were labeled with DIG and used for hybridization. The hybridizing signals were visualized by exposing the membrane to X-ray film for $2 \mathrm{~h}$. The position of the internal T-DNA fragment comprising the $S N 2$ gene $(1.65 \mathrm{~kb}$, a, left $)$ or ELP cDNA $(1.35 \mathrm{~kb}, \mathbf{b}$, left $)$ is marked with an arrow. The position of the less intense signal corresponding to junction fragment in lanes $\mathrm{S} 15$ (a, right), E3 and E22 (b, right) are indicated by black arrows. One kb ladder was used as the DNA molecular size standard and the sizes of the $1 \mathrm{~kb}$ ladder fragments are positioned on the right 
plants (S9, S14 and S15) possessed single copy of integrated T-DNA while one plant (S6) had two integrated T-DNA copies. The band corresponding to the single copy T-DNA insertion in S15 was less intense. Upon BamHI digestion of genomic DNA from ELP primary transformants, LB junction fragments longer than $4.4 \mathrm{~kb}$ are expected to hybridize (Fig. S2B). All four $T_{0}$ plants generated junction fragments longer than $4.4 \mathrm{~kb}$ and possessed a single copy of integrated T-DNA. The band obtained from plant E3 was not clearly visible in the Southern blot (Fig. 2b, right). However, plant E3 was clearly shown to contain the ELP transgene in the internal T-DNA fragment analysis (Fig. 2b, left).

\section{Transgene inheritance}

All transgenic lines grown in the greenhouse were similar to control plants in morphology, growth, fruiting and seed production. Prior to segregation analysis, a sensitivity assay was performed using seeds of NT control plants to determine the effective kanamycin concentration that could arrest seedling growth and rooting. A concentration of $100 \mathrm{mg} / \mathrm{l}$ kanamycin was chosen as an effective dosage (Fig. $\mathrm{S} 4 \mathrm{~A}$ ). Seeds of $\mathrm{T}_{0}$ lines over-expressing $\mathrm{SN} 2$ (S6, S9 and S14) or ELP (E12, E22 and E24) were surfacesterilized and placed on half-strength MS medium containing $100 \mathrm{mg} / \mathrm{l}$ kanamycin. The $\mathrm{T}_{1}$ seedlings were scored for kanamycin resistance $\left(\operatorname{Kan}^{\mathrm{R}}\right)$ and the data was validated by $\chi^{2}$-analysis (Table 1 ). The $\mathrm{Kan}^{\mathrm{R}} \mathrm{T}_{1}$ seedlings of $S N 2$ and ELP over-expressing $\mathrm{T}_{0}$ lines were taller with branched roots and reduced or no anthocyanin pigmentation in the hypocotyls similar to seedlings of NT control grown on medium without kanamycin (Fig. S4B, C, top). The assay for scoring $\operatorname{Kan}^{\mathrm{R}} \mathrm{T}_{1}$ seedlings was validated by PCR with $n p t$ II-specific primers (Table S1). The amplification of a $625 \mathrm{bp}$ fragment specific to the nptII coding sequence only in $\mathrm{Kan}^{\mathrm{R}}$ seedlings (Fig. S4B, C, bottom) confirmed the sensitivity of the kanamycin segregation assay. Segregation of $\operatorname{Kan}^{\mathrm{R}} / \operatorname{Kan}^{\mathrm{S}} \mathrm{T}_{1}$ plants of the lines S9, S14, E12, E22 and E24 was in a 3:1 ratio indicating the presence of copies of the T-DNA at single loci. In the case of line S6, the segregation ratio was 15:1, suggesting the presence of T-DNA copies in two unlinked loci. The results obtained in the segregation analysis correlated with
Table 1 Segregation analysis of $T_{1}$ tomato plants overexpressing snakin-2 (S) or extensin-like protein (E) transgene

\begin{tabular}{|c|c|c|c|c|c|}
\hline \multirow[t]{2}{*}{$\mathrm{T}_{0}$ plant number } & \multicolumn{3}{|c|}{ Number of seedlings ${ }^{\mathrm{a}}$} & \multirow[t]{2}{*}{$\chi^{2}$ value $^{b}$} & \multirow[t]{2}{*}{$P$} \\
\hline & Total & $\operatorname{Kan}^{\mathrm{R}}$ & $\mathrm{Kan}^{\mathrm{S}}$ & & \\
\hline S6 & 148 & 138 & 10 & $0.118(15: 1)$ & $>0.7$ \\
\hline S9 & 126 & 88 & 38 & $2.095(3: 1)$ & $>0.1$ \\
\hline S14 & 152 & 122 & 30 & $2.241(3: 1)$ & $>0.1$ \\
\hline E12 & 167 & 128 & 39 & $0.286(3: 1)$ & $>0.5$ \\
\hline E22 & 119 & 85 & 34 & $0.645(3: 1)$ & $>0.3$ \\
\hline E24 & 163 & 120 & 43 & $0.129(3: 1)$ & $>0.7$ \\
\hline
\end{tabular}

${ }^{\text {a }}$ Seeds were surface sterilized and placed on medium containing $100 \mathrm{mg} / \mathrm{l}$ kanamycin. Kanamycin-resistant $\left(\mathrm{Kan}^{\mathrm{R}}\right)$ and kanamycin-sensitive $\left(\mathrm{Kan}^{\mathrm{S}}\right)$ seedlings were scored after 10 days

b $\chi^{2}$ value is calculated for inheritance of one copy (3:1) or two copies $(15: 1)$ of the transgene

the number of T-DNA copies determined in the $\mathrm{T}_{0}$ transformed plants by Southern analysis.

Analysis of $S N 2$ and ELP expression in $\mathrm{T}_{1}$ stem tissues

Because our bioassays involve inoculation of stem tissues with $\mathrm{Cmm}$, it was necessary to confirm the over-expression of the transgene in stem tissues of $\mathrm{T}_{1}$ progeny. For this analysis, we used semi-quantitative RT-PCR to determine the transcript levels of $S N 2$ and $E L P$ in the stems of representative $\operatorname{Kan}^{\mathrm{R}} \mathrm{T}_{1}$ plants. Over-expression was observed in all progeny tested (Fig. 3). The SN2 transcript was over-expressed in the stem tissue of two individual $\mathrm{T}_{1}$ plants derived from each of three $\mathrm{T}_{0}$ lines when compared to the NT control plants (Fig. 3a). Like wise, ELP over-expression was detected in the two $\operatorname{Kan}^{\mathrm{R}} \mathrm{T}_{1}$ progeny plants from each of three $\mathrm{T}_{0}$ lines tested (Fig. $3 \mathrm{~b}$ ).

Enhanced tolerance of transgenic tomato plants to $\mathrm{Cmm}$

In order to assess whether the over expression of $S N 2$ and $E L P$ had any effect on tomato response to $\mathrm{Cmm}$, transgenic lines and NT control plants were challenged with the pathogen. Canker lesion severity was different between $S N 2$ and ELP over-expressing lines compared to NT control plants at 12 dpi when lesions reached their maximum size. Control plants showed a large, brown lesion spreading in both directions from 

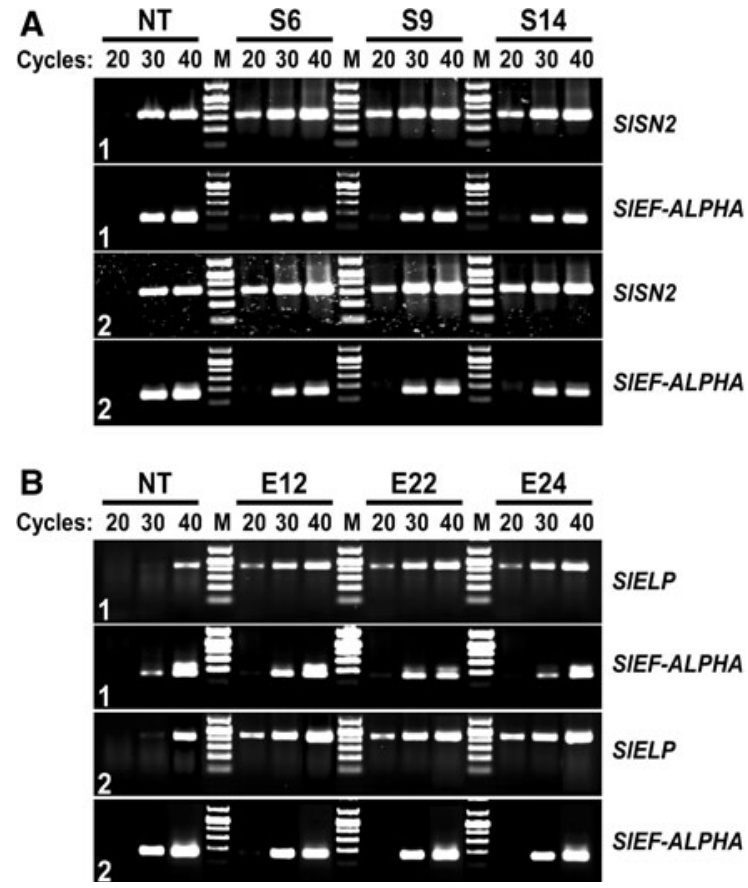

Fig. 3 Expression analysis of the $S N 2$ or ELP gene in stem tissues of the $T_{1}$ progeny of tomato $T_{0}$ plants over-expressing $S N 2$ and ELP mRNA. Total RNA was extracted from stems (one 2-cm long stem per plant) of two, 4-week-old representative $\mathrm{T}_{1}$ progeny of $S N 2$ over-expressing $\mathrm{T}_{0}$ plants $\mathrm{S} 6, \mathrm{~S} 9$ and $\mathrm{S} 14$ (a) and $E L P$ over-expressing $\mathrm{T}_{0}$ plants E12, E22 and E24 (b) and used for semi-quantitative RT-PCR analysis with genespecific primers designed to amplify SN2 and ELP cDNA or $S I E F-\alpha$ (see Table S1), as loading control. RT-PCR from a nontransformed (NT) tomato plant was included as the control. PCR products were sampled at the indicated cycles, separated on a $1 \%$ agarose gel, and visualized by ethidium bromide staining. The $1 \mathrm{~kb}$ ladder was used as the size marker $(\mathrm{M})$. The size of the $S N 2, E L P$ and $E F-\alpha$ cDNA amplicons are $315 \mathrm{bp}$, 414 and $152 \mathrm{bp}$, respectively. Numbers 1 and 2 in panels a and b refer to two independent representative $T_{1}$ plants analyzed from each transgenic line

the inoculation site, while lines over-expressing either SN2 or ELP exhibited a small lesion at the inoculation site (Figs. 4a, 5a). The severity and timing of wilt symptoms were also clearly distinguishable. At $12 \mathrm{dpi}$, wilting was severe in control plants with more leaves showing wilt, whereas lines over-expressing SN2 or ELP were mildly affected with fewer leaves wilting (Figs. 4b, 5b). As shown in Fig. 4c, in all three $S N 2$ over-expressing transgenic lines (S6, S9 and S14) the development of wilt symptoms was significantly delayed as compared with control plants. The wilting index (WI), defined as the number of days after infection at which $50 \%$ of the plants display the first wilt symptoms (Meletzus et al. 1993), was 12 days for NT control plants. Remarkably, while some plants had wilt symptoms (Fig. 4b), none of the $S N 2$ over-expressing lines reached a $50 \%$ wilting by $20 \mathrm{dpi}$. That is, none of the three lines tested had 15 of 30 plants wilting at $20 \mathrm{dpi}$ (Fig. 4c). Similar results were obtained for ELP overexpressing lines. While the control plants showed a WI of 13 days, lines E12, E22 and E24 showed a significant delay in the development of wilt symptoms and did not reach a $50 \%$ wilting even at $20 \mathrm{dpi}$ (Fig. 5c).

As an additional parameter for resistance/tolerance to $\mathrm{Cmm}$, the bacterial population size (cfu/g tissue) in planta was estimated in $S N 2$ and $E L P$ over-expressing plants. As shown in Fig. 4 d, Cmm titer was significantly lower in the SN2-over expressing lines when compared to the control plants at both 4 and 8 dpi. At $4 \mathrm{dpi}$, in control plants, $\mathrm{Cmm}$ titer had reached $1 \times 10^{8} \mathrm{cfu} / \mathrm{g}$, while in the transgenics the population sizes ranged from $1 \times 10^{6}$ to $1 \times 10^{7} \mathrm{cfu} / \mathrm{g}$ (10-100-fold less than in control plants). The bacterial population in stems of control plants continued to increase with time and by day 8 the titer had reached $1 \times 10^{11} \mathrm{cfu} / \mathrm{g}$ whereas in the SN2-over expressing lines bacterial counts were 100-1,000-fold lower (Fig. 4d).

A similar trend of bacterial growth restriction was observed in $\mathrm{T}_{1}$ progeny plants of $E L P$ over-expressing lines at both 4 and 8 dpi (Fig. 5d). At 4 dpi, in control plants the $\mathrm{Cmm}$ titer had reached $1 \times 10^{9} \mathrm{cfu} / \mathrm{g}$, while in the transgenics it ranged from $1 \times 10^{5}$ to $1 \times$ $10^{7} \mathrm{cfu} / \mathrm{g}$ (100-10,000-fold less than in control plants). At $8 \mathrm{dpi}$, the number of cfu in stems of control plants reached $1 \times 10^{12} \mathrm{cfu} / \mathrm{g}$, whereas in the ELP over-expressing lines the population size ranged from $1 \times 10^{8}$ to $1 \times 10^{9} \mathrm{cfu} / \mathrm{g}$ (Fig. $5 \mathrm{~d}$ ), accounting for a 1,000-10,000-fold difference. Similar results were obtained in an additional independent experiment (data not shown).

\section{Discussion}

The antimicrobial peptides SN1 and SN2 from potato and the cell wall-associated protein extensin have been previously implicated in resistance to bacterial diseases (Berrocal-Lobo et al. 2002; Wei and Shirsat 2006; Almasia et al. 2008). Using virus-induced gene 

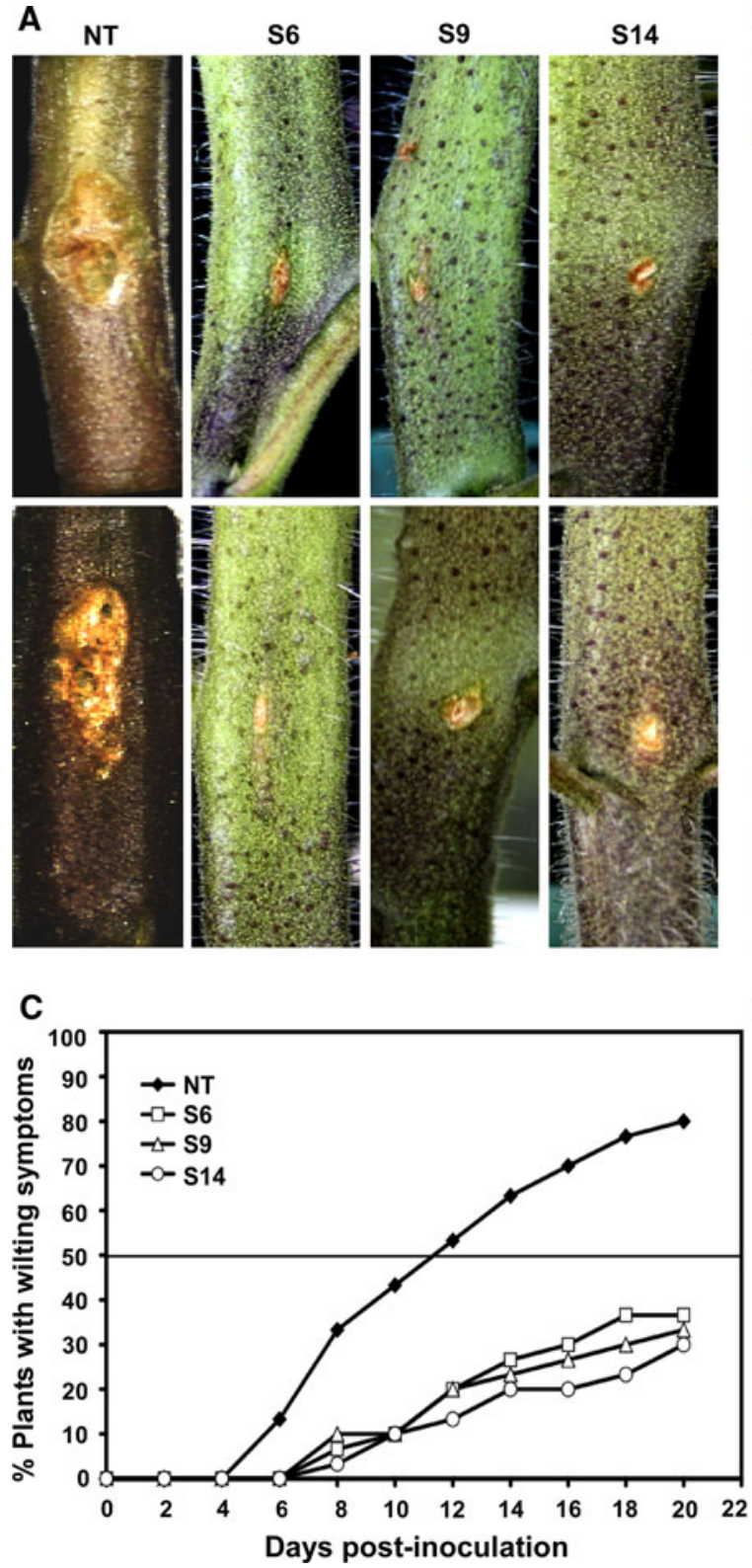

Fig. 4 Evaluation of SN2 over-expressing tomato lines for resistance to Clavibacter michiganensis subsp. michiganensis $(\mathrm{Cmm})$. A set of 30 four-week-old $\mathrm{T}_{1}$ plants of each of the $\mathrm{T}_{0}$ parents S6, S9, S14 (SN2 over-expressing lines) and nontransformed control (NT) were inoculated with a $\mathrm{Cmm}$ suspension $\left(1 \times 10^{8} \mathrm{cfu} / \mathrm{ml}\right)$ in the stem at the first leaf from the bottom and examined for development of canker lesions and wilt symptoms over a 20 day period. a Canker lesions at $12 \mathrm{dpi}$ of two independent stem samples from NT plants and $\mathrm{T}_{1}$ plants of lines S6, S9 and S14. b A representative plant from lines S6, S9 and S14 showing mild wilt symptoms and the NT control plant showing severe wilt symptoms 12 days after inoculation with $\mathrm{Cmm}$. Mockinoculated NT control and a representative plant of transgenic line S14 did not show disease symptoms. $\mathbf{c}$ The percentage of plants
B
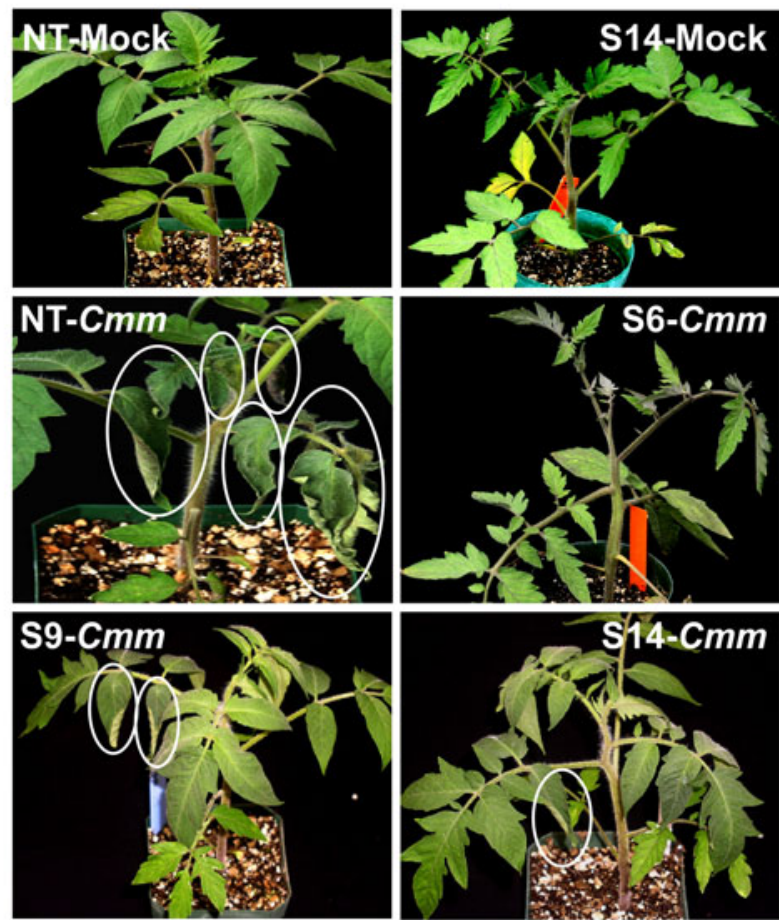

D

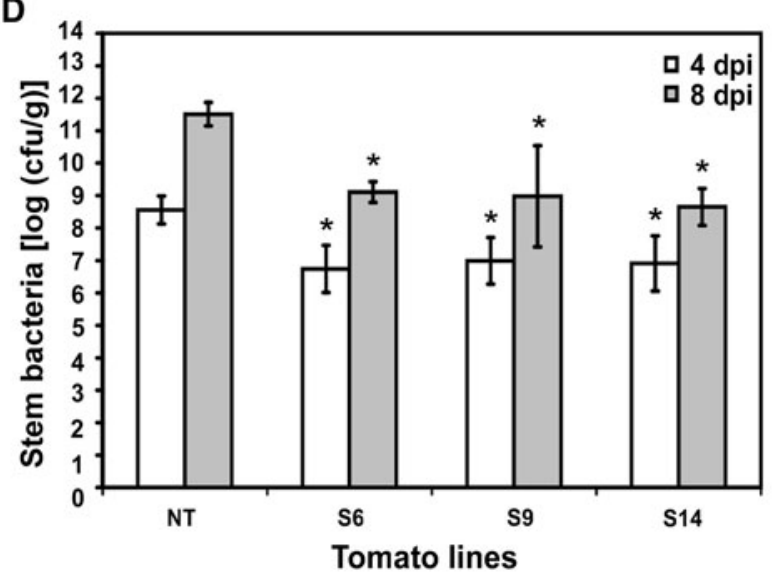

showing wilt symptoms was calculated in a group of 30 plants for each of the over-expressing lines and the control and used to determine the wilting index (WI) indicated by a line. The NT control plants showed a WI of 12 days, while transgenic lines S6, S9 and S14 did not reach $50 \%$ wilting during the 20 day experiment. d Growth of $\mathrm{Cmm}$ in stems tissues of $\mathrm{SN} 2$ overexpressing and NT tomato lines. Bacterial populations were estimated in stems of the transgenic (S6, S9 and S14) and control plants harvested at 4 and 8 days post-inoculation (dpi). Each bar represents the mean and SD derived from sampling four stems from four independent $\mathrm{T}_{1}$ plants (one stem/plant). Asterisks denote significant differences $(P<0.05)$ in the bacterial titer in transgenic plants (S6, S9 and S14) compared to NT control plants at each time point, according to Student's $t$ test 
A
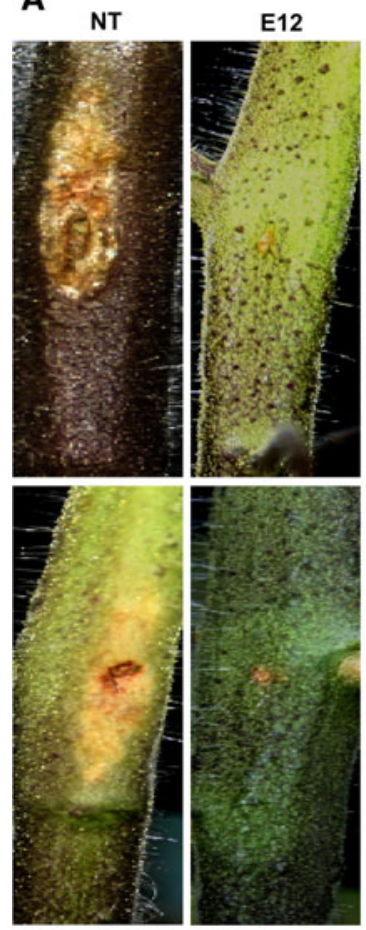

C

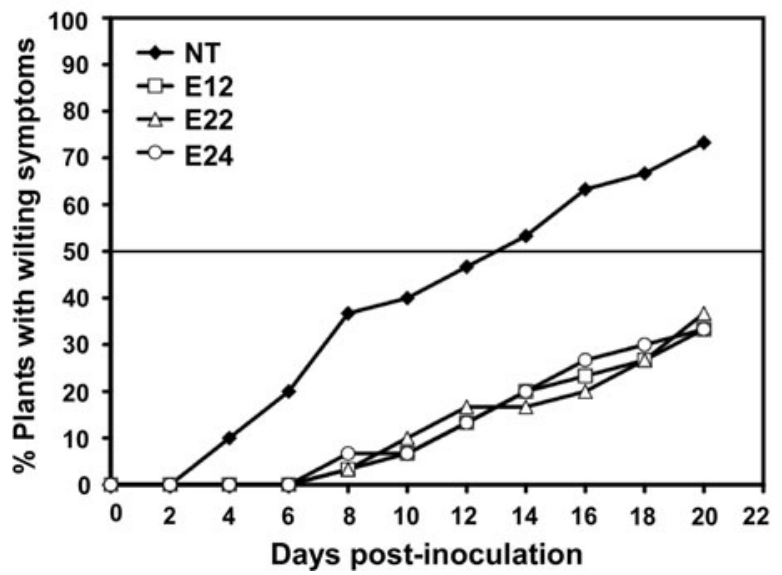

Fig. 5 Evaluation of ELP over-expressing transgenic lines for resistance to Clavibacter michiganensis subsp. michiganensis $(\mathrm{Cmm})$. A set of 30 five-week-old $\mathrm{T}_{1}$ plants of each line (E12, E22, E24) and the non-transformed control (NT) were inoculated with a $\mathrm{Cmm}$ suspension $\left(10^{8} \mathrm{cfu} / \mathrm{ml}\right)$ in the stem region at the first leaf from the bottom and examined for development of wilt symptoms during a 20 day period. a Canker lesions at $12 \mathrm{dpi}$ of two independent stem samples from NT plants and $T_{1}$ plants of lines E12, E22 and E24. b A representative plant from lines E12, E22 and E24 showing mild wilt symptoms and the NT control plant showing severe wilt symptoms 12 days after inoculation with $\mathrm{Cmm}$. Mock-inoculated NT control and a representative plant of transgenic line E22 did not show disease symptoms. c The percentage of plants showing wilt symptoms was
B
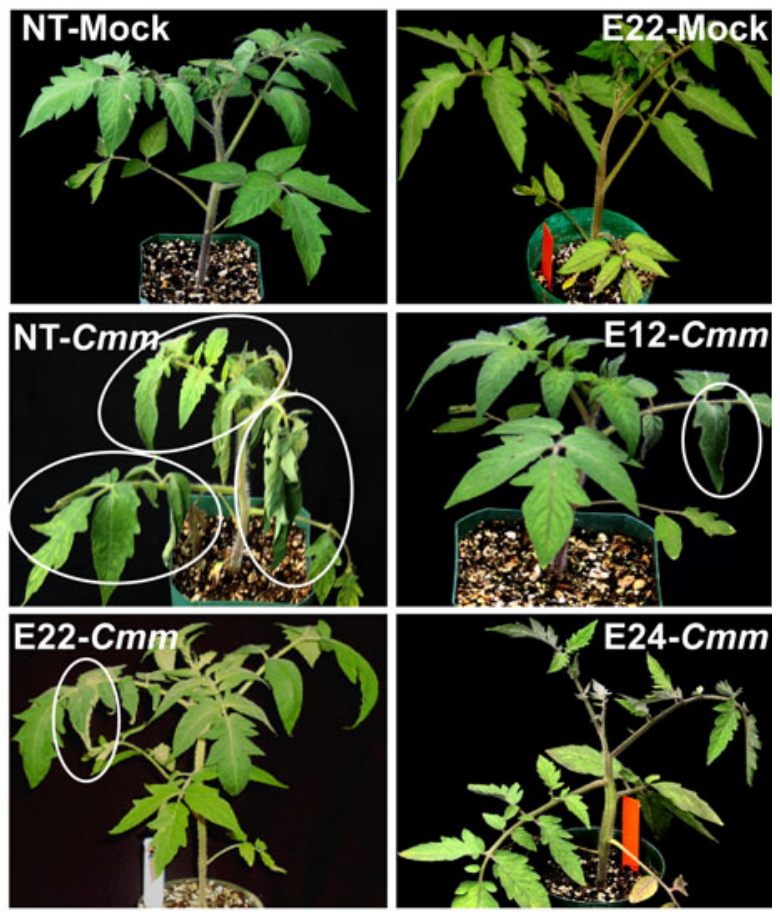

D

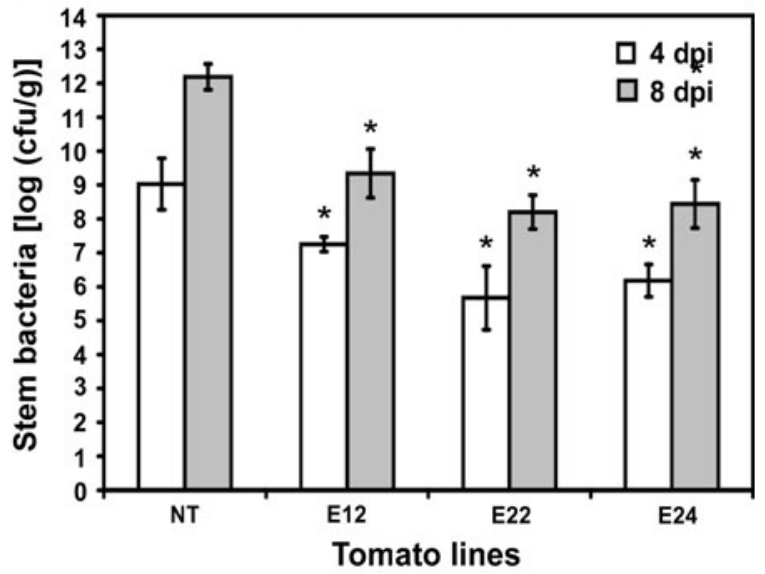

calculated in a group of 30 plants for each of the over-expressing lines and the non-transformed control and used to determine the wilting index (WI) indicated by a line. The NT control plants showed a WI of 13 days, while transgenic lines E12, E22 and E24 did not reach $50 \%$ wilting. d Growth of $\mathrm{Cmm}$ in stems tissues of ELP over-expressing and NT tomato lines. Bacterial populations were estimated in stems of the transgenic (E12, E22 and E24) and NT control plants harvested at 4 and 8 days postinoculation (dpi). Each bar represents the mean and SD derived from sampling four stems from four independent $\mathrm{T}_{1}$ plants (one stem/plant). Asterisks denote significant differences $(P<0.05)$ in the bacterial titer in transgenic plants (E12, E22 and E24) compared to NT control plants at each time point, according to Student's $t$ test 
silencing in $N$. benthamiana, we recently attributed a role to tomato SN2 and ELP homologs in basal defense response to $\mathrm{Cmm}$ (Balaji et al. 2011). In this study, we explored the defense-related function of tomato SN2 and ELP genes and their potential use for development of transgenic tomato plants with resistance or tolerance to $\mathrm{Cmm}$. To this aim, we used the gain-of-function approach by over-expressing them in transgenic tomato plants.

SN2 was originally isolated from potato (Solanum tuberosum) and is a member of the widely divergent snakin/GASA (giberellic acid stimulated in Arabidopsis) family (Segura et al. 1999). StSN1 and StSN2 are the only known members representing subfamilies I and II (Segura et al. 1999; Berrocal-Lobo et al. 2002). To our knowledge, this is the first report on the isolation of a full-length tomato SN2 gene and development of transgenic tomato lines with enhanced tolerance to $\mathrm{Cmm}$. The tomato SN2 protein has the conserved 12 cysteine residues in the $\mathrm{C}$-terminus region, characteristic of snakin/GASA family. Comparative sequence analyses of tomato and potato SN2 genes revealed a high level of identity and evolutionary conservation.

A Cmm bioassay of $S N 2$ over-expressing $\mathrm{T}_{1}$ plants (hemizygous or homozygous for the transgene) was carried out to analyze whether these lines acquired enhanced tolerance to bacterial canker and wilt. Symptom development and bacterial populations were significantly reduced in the SN2 over-expressing transgenic plants. The tested transgenic lines did not display significant differences in the level of resistance to Cmm. SN2 transcript accumulation levels in leaves were similar in lines S9 and S14, but line S6 appeared to have less $S N 2$ mRNA (Fig. 1a). It is possible that the region flanking the inserts could alter temporal or tissue-specific expression patterns. More research needs to be done to clarify this point. Unfortunately, attempts to express SN2 in a bacterial expression system failed, making it impossible to evaluate the peptide levels in transgenic lines. It is possible that the intrinsic antimicrobial activity of SN2 may affect the viability of the expression system.

The hypothesis of a defense role for the $S N 2$ gene is well supported by previous studies of closely related SN1 gene and its homologous genes (Thornburg et al. 2003; Bindschedler et al. 2006; Almasia et al. 2008; Kovalskaya and Hammond 2009). In the present study, we report that tolerant SN2 over-expressing transgenic lines exhibited a reduction in canker lesion size, in planta bacterial population size and wilting symptoms when challenged with $\mathrm{Cmm}$. Although no information is yet available concerning the mechanism of action of SN1 and SN2, it was proposed that observed aggregation of both Gram-negative and Gram-positive bacteria in vitro might play a role in vivo through the control of pathogen migration (Segura et al. 1999; BerrocalLobo et al. 2002; Kovalskaya and Hammond 2009). Moreover, snakin peptides show sequence similarity with cysteine-rich domains of proteins from animals that are involved in protein-protein interactions playing an important role to control pathogens in vivo (Berrocal-Lobo et al. 2002). Recently, a chitinbinding proline-rich protein from French bean that has been previously characterized through its involvement in plant-pathogen interactions was shown to be composed of two components: a proline-rich polypeptide and a 12-cysteine peptide with amino acid similarity to snakins (Bindschedler et al. 2006). Yet, the defence role proposed for SN2 is not incompatible with the involvement of this gene in other plant processes, functions and mechanisms. Importantly, over-expression of the StSN1 gene in transgenic potato plants was shown to confer enhanced resistance to bacterial and fungal pathogens (Almasia et al. 2008). Because of the fact that SN1 and SN2 peptides contain putative redox-active cysteines, these proteins could be involved in redox regulation. It is well known that reactive oxygen species (ROS) are involved in pathogenesis and wounding. Recently, it has been shown that GIP2 (another GASA-like protein) from Petunia $\times$ hybrida regulates ROS levels (Wigoda et al. 2006). Consequently, SN1, SN2 as well as all members of this peptide family may also act as antioxidants.

Previous studies have proposed a correlation between extensin synthesis and plant defense due to the structural nature of the protein that is cell wallassociated (Showalter 1993; Cassab 1998) and the fact that genes encoding extensin and ELPs are transcriptionally activated upon pathogen attack (Merkouropoulos and Shirsat 2003; Balaji et al. 2008). A tomato ELP transcript (Van den Heuvel et al. 2002) was shown to be significantly up-regulated when challenged with $\mathrm{Cmm}$ (Balaji et al. 2008). Furthermore, virus-induced gene silencing-mediated suppression of the $N$. benthamiana homolog of tomato ELP increased susceptibility to $\mathrm{Cmm}$ infection and induced early development 
of typical wilt symptoms (Balaji et al. 2011) implicating a role for them in basal defense response to $\mathrm{Cmm}$. Results from this study showed that tomato plants overexpressing ELP transcript displayed enhanced tolerance to $\mathrm{Cmm}$ infection as evident from a reduction in canker lesion size, in planta bacterial population size and wilting symptoms. As observed in SN2 overexpressing plants, lines E22 and E24 accumulated ELP transcript to a comparable level, but a relatively lower level of transcript accumulation was seen in line E12 (Fig. 1b). Therefore, we cannot discard the possibility that the region flanking the inserts could alter expression patterns.

The tomato ELP protein is rich in proline and cysteine residues with cysteines mainly distributed in the C-terminus region (Van den Heuvel et al. 2002), a feature characteristic of cysteine-rich extensin-like proteins (CELP) of tobacco (Wu et al. 1993). Structurally, being proline-rich proteins with low tyrosine contents, the CELPs must rely on chemical reactions other than the irreversible isodityrosine linkages presumably utilized by the tyrosine-rich HRGPs, including extensins, to integrate into the cellwall network (Epstein and Lamport 1984; Fry 1988). It is likely that the cysteine residues play a role in this aspect and participate in disulfide bond formation under the proper oxidative-reductive conditions, which along with other domains may be available for interactions with structures contiguous to the cell walls. The formation of a cross-linked network in the cell wall has been hypothesized to slow the spread of the pathogen prior to the activation of transcriptiondependent defences. In addition to altering the composition of the cell wall, ELPs and extensin proteins may directly agglutinate bacteria and help prevent further proliferation. Another hypothesis (Mazau et al. 1987) proposes that extensins may immobilize pathogens by binding to their surfaces, as extensins and ELPs are positively charged and most pathogens carry a net negative surface charge (Mellon and Helgeson 1982). Immobilization of bacterial pathogens by agglutination, if it occurs, may allow time for the build-up of compounds which directly result in the death of invading bacteria and a reduction in their numbers. It is possible that this might be the mechanism operating in the ELPoverexpressing transgenic tomato lines. It is obvious that the cell wall, being a barrier to pathogen entry, is dynamically remodeled to prevent the ingress of pathogens, and it has long been proposed (Vance et al. 1980) that cell wall fortification occurs in response to pathogen attack, making the walls more resistant to further infection.

It is well known that in addition to the CelA encoded endoglucanase, other extracellular enzymes such as polygalacturonase (Beimen et al. 1992), pectinmethylesterase (Strider 1969), and xylanase (Beimen et al. 1992) produced by $\mathrm{Cmm}$ may also be involved in the degradation of the composite polymeric cell wall structure. It has been proposed that wilting is caused by hydrolytic degradation of xylem vessel walls by CelA resulting in an impairment of water transport by embolisms and lateral spread of bacteria into adjacent stem parenchyma accompanied by tissue maceration (Jahr et al. 2000). From our results, it is tempting to speculate that due to ELP over expression-mediated fortification, the cell wall is likely to be less amenable for degradation by $\mathrm{Cmm}$ thus reducing the supply of nutrients for growth. Consequently colonization is retarded and development of disease symptoms is significantly delayed in transgenic lines.

In the present study, transgenic tomato over expressing SN2 and ELP did not exhibit visual phenotypic differences from wild-type in the greenhouse, suggesting that constitutive over-expression of these proteins did not alter plant physiology. Our data suggest that $S N 2$ and ELP are interesting candidate genes for genetically engineering tomato plants to confer protection against the economically important pathogen $\mathrm{Cmm}$. Furthermore, since both proteins are known to be involved in the resistance to a range of pathogen infections, it would be very interesting to determine the spectra of resistance of these transgenic plants against several known pathogens of tomato.

Acknowledgments We thank Holly Lange and Kevin Conley for maintaining plants in the greenhouse. This research was supported by the New York State Agricultural Experiment Station and the United States-Israel Binational Agricultural Research and Development Fund (award No. IS-4047-07).

\section{References}

Almasia NI, Bazzini AA, Hopp HE, Vazquez-Rovere C (2008) Overexpression of snakin-1 gene enhances resistance to Rhizoctonia solani and Erwinia carotovora in transgenic potato plants. Mol Plant Pathol 9:329-338 
Balaji V, Mayrose M, Sherf O, Jacob-Hirsch J, Eichenlaub R, Iraki N, Manulis-Sasson S, Rechavi G, Barash I, Sessa G (2008) Tomato transcriptional changes in response to Clavibacter michiganensis subsp. michiganensis reveal a role for ethylene in disease development. Plant Physiol 146:1797-1809

Balaji V, Sessa G, Smart CD (2011) Silencing of host basal defense response-related gene expression increases susceptibility of Nicotiana benthamiana to Clavibacter michiganensis subsp. michiganensis. Phytopathology 101: 349-357

Beimen A, Bermpohl A, Meletzus D, Eichenlaub R, Barz W (1992) Accumulation of phenolic compounds in leaves of tomato plants after infection with Clavibacter michiganense subsp. michiganense strains differing in virulence. Z Naturforsch 47C:898-909

Ben-Nissan G, Weiss D (1996) The petunia homologue of tomato gast 1: transcript accumulation coincides with gibberellin-induced corolla cell elongation. Plant Mol Biol 32:1067-1074

Berrocal-Lobo M, Segura A, Moreno M, Lopez G, GarciaOlmedo F, Molina A (2002) Snakin-2, an antimicrobial peptide from potato whose gene is locally induced by wounding and responds to pathogen infection. Plant Physiol 128:951-961

Bindschedler LV, Whitelegge JP, Millar DJ, Bolwell GP (2006) A two component chitin-binding protein from French bean-association of a proline-rich protein with a cysteine-rich polypeptide. FEBS Lett 580:1541-1546

Bowles DJ (1990) Defence-related proteins in higher plants. Annu Rev Biochem 59:873-907

Cassab GI (1998) Plant cell wall proteins. Annu Rev Plant Physiol 49:281-309

Chalupowicz L, Cohen-Kandli M, Dror O, Eichenlaub R, Gartemann K-H, Sessa G, Barash I, Manulis-Sasson S (2010) Sequential expression of bacterial virulence and plant defense genes during infection of tomato with Clavibacter michiganensis subsp. michiganensis. Phytopathology 100:252-261

Chang S, Puryear J, Cairney J (1993) A simple and efficient method for isolating RNA from pine trees. Plant Mol Biol Rep 11:113-116

Chee PP, Fober KA, Slightom JL (1989) Transformation of soybean (Glycine max) by infecting germinating seeds with Agrobacterium tumefaciens. Plant Physiol 91:12121218

Chilton M-D, Currier TC, Farrand SK, Bendich AJ, Gordon MP, Nester EW (1974) Agrobacterium tumefaciens DNA and PS8 bacteriophage DNA not detected in crown gall tumors. Proc Natl Acad Sci USA 71:3672-3676

Chun WCC (1982) Identification and detection of Corynebacterium michiganense in tomato seed using the enzymelinked immunosorbent assay. MS thesis, University of Hawaii, Honolulu

Davies HA, Daniels MJ, Dow JM (1997) Induction of extracellular matrix glycoproteins in Brassica petioles by wounding and in response to Xanthomonas campestris. Mol Plant Microbe Interact 10:812-820

Davis MJ, Gillespie JA, Vidaver AK, Harris RW (1984) Clavibacter: a new genus containing some phytopathogenic coryneform bacteria, including Clavibacter xyli subsp. xyli sp. nov., subsp. nov. and Clavibacter xyli subsp. cynodontis subsp. nov., pathogens that cause ratoon stunting disease of sugarcane and bermudagrass stunting disease. Int J Syst Bacteriol 34:107-117

Epstein L, Lamport DTA (1984) An intramolecular linkage involving isodityrosine in extensin. Phytochemistry 23:1241-1246

Fry SC (1988) The growing plant cell wall: chemical and metabolic analysis. The Blackburn Press, Caldwell

Furukawa T, Sakaguchi N, Shimada H (2006) Two OsGASR genes, rice GAST homologue genes that are abundant in proliferating tissues, show different expression patterns in developing panicles. Genes Genet Syst 81:171-180

Gartemann KH, Kirchner O, Engemann J, Grafen I, Eichenlaub R, Burger A (2003) Clavibacter michiganensis subsp. michiganensis: first step in understanding of virulence of a Gram-positive phytopathogenic bacterium. J Biotechnol 106:179-191

Gartemann K-H, Abt B, Bekel T, Burger A, Engemann J, Flügel M, Gaigalat L, Goesmann A, Grafen I, Kalinowski J, Kaup O, Kirchner O, Krause L, Linke B, McHardy A, Meyer F, Pohle S, Ruckert C, Schneiker S, Zellermann E-M, Puhler A, Eichenlaub R, Kaiser O, Bartels D (2008) The genome sequence of the tomato-pathogenic actinomycete Clavibacter michiganensis subsp. michiganensis NCPPB382 reveals a large island involved in pathogenicity. J Bacteriol 190:2138-2149

Hauck P, Thilmony R, He SY (2003) A Pseudomonas syringae type 111 effector suppresses cell wall-based extracellular defense in susceptible Arabidopsis plants. Proc Natl Acad Sci USA 100:8577-8582

Hoekema A, Hirsch PR, Hooykaas PJJ, Schilperoort RA (1983) A binary plant vector strategy based on separation of virand T-region of the Agrobacterium tumefaciens Ti-plasmid. Nature 303:179-180

Jahr H, Bahro R, Burger A, Ahlemeyer J, Eichenlaub R (1999) Interactions between Clavibacter michiganensis and its host plants. Environ Microbiol 1:113-118

Jahr H, Dreier J, Meletzus D, Bahro R, Eichenlaub R (2000) The endo-b-1, 4-glucanase CelA of Clavibacter michiganensis subsp. michiganensis is a pathogenicity determinant required for induction of bacterial wilt of tomato. Mol Plant Microbe Interact 13:703-714

Jakobek JL, Smith JA, Lindgren PB (1993) Suppression of bean defense responses by Pseudomonas syringae. Plant Cell 5:57-63

Jones JB, Jones JP, Stall RE, Zitter TA (1991) Compendium of tomato diseases. APS Press, St. Paul

Kotilainen M, Helariutta Y, Mehto M, Pollanen E, Albert VA, Elomaa P, Teeri TH (1999) GEG participates in the regulation of cell and organ shape during corolla and carpel development in gerbera hybrida. Plant Cell 11:1093-1104

Kovalskaya N, Hammond RW (2009) Expression and functional characterization of the plant antimicrobial snakin-1 and defensin recombinant proteins. Protein Expr Purif 63:12-17

Ling KS, Zhu HY, Alvizo H, Hu JS, Drong RF, Gonsalves D (1997) The coat protein gene of grapevine leafroll associated closterovirus-3: cloning, nucleotide sequencing and expression in transgenic plants. Arch Virol 142:11011116 
Lopez-Solanilla E, Gonzalez-Zorn B, Novella S, VazquezBoland JA, Rodriguez-Palenzuela P (2003) Susceptibility of Listeria monocytogenes to antimicrobial peptides. FEMS Microbiol Lett 226:101-105

Mazau D, Rumeau D, Esquerré-Tugayé MT (1987) Molecular approaches to understanding cell-surface interactions between plants and fungal pathogens. Plant Physiol Biochem 25:337-343

Meletzus D, Bermpohl A, Drier J, Eichenlaub R (1993) Evidence for plasmid-encoded virulence factors in the phytopathogenic bacterium Clavibacter michiganensis subsp. michiganensis NCPPB382. J Bacteriol 175:2131-2136

Mellon J, Helgeson J (1982) Interaction of a hydroxyprolinerich glycoprotein from tobacco callus with potential pathogens. Plant Physiol 70:401-405

Merkouropoulos G, Shirsat AH (2003) The unusual Arabidopsis extensin gene EXT1 is expressed throughout plant development and is induced by a variety of biotic and abiotic stresses. Planta 217:356-366

Murashige T, Skoog F (1962) A revised medium for rapid growth and bio assays with tobacco tissue cultures. Physiol Plant 15:473-497

Rogers SO, Bendich AJ (1988) Extraction of total cellular DNA from plants. In: Gelvin SB, Schilperoort RA, Verma DPS (eds) Plant molecular biology manual. Kluwer Academic Publishers, Netherlands, pp A6/1-A6/10

Sambrook J, Fritsch EF, Maniatis T (1989) Molecular cloning: a laboratory manual, 2nd edn. Cold Spring Harbor Laboratory Press, Cold Spring Harbor

Segura A, Moreno M, Madueno F, Molina A, Garcia-Olmedo F (1999) Snakin-1, a peptide from potato that is active against plant pathogens. Mol Plant Microbe Interact 12: $16-23$

Selitrennikoff CP (2001) Antifungal proteins. Appl Environ Microbiol 67:2883-2894

Shi L, Gast RT, Gopalraj M, Olszewski NE (1992) Characterization of a shoot-specific, GA3 and ABA-regulated gene from tomato. Plant J 2:153-159

Showalter AM (1993) Structure and function of plant cell wall proteins. Plant Cell 5:9-23

Showalter A, Rumeau D (1990) Molecular biology of the plant cell wall hydroxyproline-rich glycoproteins. In: Adair W, Mercham R (eds) Organisation and assembly of plant and animal extracellular matrix. Academic Press, New York, pp 247-281

Showalter AM, Varner JE (1989) Plant hydroxyproline-rich glycoproteins. In: Stumpf PK, Conn EE (eds) The biochemistry of plants: a comprehensive treatise. Academic Press, New York, pp 485-520

Sommer-Knudsen J, Bacic A, Clarke AE (1998) Hydroxyproline-rich plant glycoproteins. Phytochemitsry 47:483-497

Strider DL (1969) Bacterial canker of tomato caused by Corynebacterium michiganense. A literature review and bibliography. North Carolina agricultural experiment station technical bulletin, no. 193

Thompson JD, Higgins DG, Gibson TJ (1994) CLUSTAL W: improving the sensitivity of progressive multiple sequence alignment through sequence weighting, position specific gap penalties and weight matrix choice. Nucleic Acids Res 22:4673-4680

Thornburg RW, Carter C, Powell A, Mittler R, Rizhsky L, Horner HT (2003) A major function of the tobacco floral nectary is defense against microbial attack. Plant Syst Evol 238:211-218

Van den Heuvel KJ, Lipzig RHV, Barendse GW, Wullems GJ (2002) Regulation of expression of two novel flowerspecific genes from tomato (Solanum lycopersicum) by gibberellin. J Exp Bot 53:51-59

Van Eck J, Kirk DD, Walmsley AM (2006) Tomato (Lycopersicum esculentum). In: Wang K (ed) Molecular biology: Agrobacterium protocols. Humana Press, Totowa, pp 459-473

Vance CP, Kirk TK, Sherwood RT (1980) Lignification as a mechanism of disease resistance. Annu Rev Phytopathol 18:259-288

Wei G, Shirsat AH (2006) Extensin over-expression in Arabidopsis limits pathogen invasiveness. Mol Plant Pathol 7:579-592

Wigoda N, Ben-Nissan G, Granot D, Schwartz A, Weiss D (2006) The gibberellin-induced, cysteine-rich protein GIP2 from Petunia hybrida exhibits in planta antioxidant activity. Plant J 48:796-805

Wu H-M, Zou J, May B, Gu Q, Cheung AY (1993) A tobacco gene family for flower cell wall proteins with a prolinerich domain and a cysteine-rich domain. Proc Natl Acad Sci USA 90:6829-6833 